\title{
Investigasi Patahan Manado di Pesisir Teluk Manado Sebagai Upaya Mitigasi Bencana Alam
}

\author{
As'ari As'aria*, Seni Herlina Juita Tongkukuta, Sarmaria Panjaitana, Iftita \\ Anugraini Akasia, Meidy Rosalie Pulua \\ aJurusan Fisika, FMIPA, Universitas Sam Ratulangi, Manado
}

KATA K U N C I

Patahan Manado

Pesisir Manado

K E Y W O R D S

Manado Fault

Manado Coast

\begin{abstract}
A B S TR A K
Daerah sumber gempa bumi biasanya terdapat pada patahan-patahan yang aktif dan daerah batas lempeng. Data sumber gempa dibutuhkan sebagai bahan evaluasi potensi bencana alam gempa bumi. Sulawesi Utara merupakan daerah yang mempunyai posisi dekat dengan pertemuan tiga lempeng, yaitu Lempeng Pasifik, Lempeng Eurasia dan Lempeng Indo Australia. Patahan Manado merupakan satu patahan yang terdapat di Sulawesi Utara melewati Kota Manado. Keberadaan patahan di pesisir Kota Manado memerlukan identifikasi lebih lanjut menggunakan survei geofisika bawah permukaan. Penelitian bertujuan mengidentifikasi parameter fisis patahan di Pesisir pantai Kota Manado. Eksplorasi dilakukan menggunakan metode geolistrik tahanan jenis konfigurasi dipol-dipol. Data diolah dengan menggunakan perangkat lunak Res2dinv, dan dihasilkan tampang lintang resistivitas 2 dimensi bawah permukaan bumi. Pada lintasan 1 yang terletak di reklamasi pantai, Patahan Manado diidentifikasi sebagai rekahan dengan nilai resistivitas $\rho \leq 20 \Omega \mathrm{m}$, lebar patahan 10-60 m dan kedalaman sampai $20 \mathrm{~m}$. Pada lintasan 2 yang terletak di daratan rekahan dengan nilai resistivitas $\leq 128 \Omega \mathrm{m}$, lebar patahan 10-40 m dan kedalaman sampai $20 \mathrm{~m}$. Rekahan pada lintasan 1 terisi material yang mengandung air laut, sedang rekahan pada lintasan 2 terisi material yang mengandung air tawar. Akuifer air tawar di daratan pesisir pada jalur patahan tidak terintrusi oleh air laut
\end{abstract}

A B S T R A C T
The source areas for earthquakes are usually at active faults and plate boundary areas.
Earthquake source data are needed as material for evaluate the potentiation of
earthquake natural disaster. North Sulawesi is an area that has a position close to the
meeting point of three plates, namely the Pacific Plate, Eurasian Plate and the Indo-
Australian Plate. The Manado Fault is a fault located in North Sulawesi through the city
of Manado. The existence of the fault on the coast of Manado City requires further
identification using subsurface geophysical surveys. This study aims to identify the
physical parameters of the fault on the coast of Manado City. Exploration is carried out
using the geoelectric resistivity method of dipole-dipole configuration. The data is
processed using Res 2 dinv software, and the result is a 2 -dimensional resistivity cross
section of the earth subsurface. On line 1 which is located at beach reclamation, the
Manado Fault is identified as a fracture with a resistivity value of $\rho \leq 20 \Omega$ m, a fault
width of $10-60$ m and a depth of up to 20 m. On line 2 which is located on the fracture
land with a resistivity value $\rho \leq 128 \Omega$ m, the fault width is $10-40$ m and a depth of up to
20 m. The fracture on track 1 is filled with material containing sea water, while the
fracture on line 2 is filled with material containing fresh water. Freshwater aquifers in
coastal land on the fault line are not intruded by sea water

TERSEDIA ONLINE

01 Februari 2021
Lempeng Eurasia dan Lempeng Ausralia. Zona subduksi antara Lempeng Eurasia dan Lempeng Pasifik menggerakkan lempeng-lempeng mikro di daerah ini. Sebagai akibatnya di Sulawesi Utara sering 
terjadi gempa bumi. Pola patahan di lengan Utara Sulawesi telah terbentuk sebagai akibat dari pergerakan lempeng Laut Sulawesi dari utara dan selatan serta lempeng mikro Tomini dari selatan. Efek dari keduanya menekan dari utara dan selatan, piring lengan utara Sulawesi bergerak ke timur yang bertabrakan dengan pergerakan ke barat lempeng samudera pulau Maluku (bentuk-K Halmahera) (Siahaan, et al., 2005).

Patahan-patahan yang terdapat di Sulewesi Utara antara lain: Patahan Manado, Patahan Amurang dan Patahan Mongondow. Patahanpatahan ini membentang sepanjang daratan sampai ke daerah pesisir pantai. Menurut Effendi dan Bawono, 1997 bahwa Patahan Manado yang melintasi wilayah Kota Manado menurut Peta Geologi lembar Manado diperkirakan berada pada lokasi tepat di bawah kota Manado-Ketang-SorengsongPaslaten-Karegesan-Tontalete pada satu garis lurus.

Patahan merupakan sumber gempa yang jarang dan langka dipetakan. Gempa yang bersumber di patahan akan memberikan dampak kerusakan yang besar khususnya pada kawasan yang dilalui patahan. Patahan Manado sudah lama tidak aktif semenjak terbentuknya, namun demikian kewaspadaan diperlukan karena diperkirakan terjadi akumulasi energy dibidang patahan. Jika energinya cukup maka akan terjadi pergeseran atau pergerakan pada patahan tersebut. Bangunan infrastruktur yang dibangun tepat pada jalur patahan akan menperoleh efek guncangan gempa paling besar ketika gempa terjadi. Penentuan lokasi persis suatu patahan aktif di permukaan, tidak cukup hanya dari bentang alam dan geologi tetapi harus dibantu dengan survei geofisika bawah permukaan seperti dengan metode geolistrik.

Metode geolistrik tahanan jenis mempunyai beberapa jenis konfigurasi, antara lain : dipol-dipol, Wenner alpha, Wenner beta, Wenner-Schlumberger, pol dipol, pol pol. Konfigurasi dipol-dipol merupakan salah satu konfigurasi yang sering dilakukan dalam eksplorasi metode geolistrik tahanan jenisPada konfigurasi Dipol-dipol, dua elektroda arus dan dua elektroda potensial ditempatkan terpisah dengan jarak na, sedangkan jarak masing-masing elektroda a. Pengukuran dilakukan dengan memindahkan elektroda potensial pada suatu penampang dengan elektroda arus tetap, kemudian pemindahan elektroda arus pada spasi $n$ berikutnya diikuti oleh pemindahan elektroda potensial sepanjang lintasan seterusnya hingga pengukuran elektroda arus pada titik terakhir di lintasan itu (Burbey dan Seaton, 2002)

Kota Manado terletak di pesisir Teluk Manado, daerah yang padat penduduk dan pembangunan infrastruktur yang pesat. Jalur Patahan Manado melewati kawasan pantai di Kecamatan Tuminting. Antisipasi dan mitigasi bencana pesisir sangat perlu dilakukan. Bencana pesisir adalah kejadian karena peristiwa alam atau karena perbuatan orang yang menimbulkan perubahan sifat fisik dan/atau hayati pesisir dan mengakibatkan korban jiwa, harta, dan/atau kerusakan di Wilayah Pesisir dan PulauPulau Kecil (UU No 27, 2007).

Struktur patahan dan rekaman gempabumi yang mencakup beberapa siklus seismik sangat penting untuk mengevaluasi perilaku patahan, interaksi patahan, distribusi stress dan bencana seismik (Pondard and Barnes, 2010).

Karakteristik batuan yang terdapat di Pantai Teluk Manado adalah spesifik, berbeda dengan batuan yang terletak jauh dari pantai. Endapan sedimen karena pola arus, akan memberikan reaksi tertentu pada energi gempabumi. Riset pola patahan di pesisir pantai Teluk Manado belum pernah dilakukan, sehingga informasi datanya sangat minim. Eksplorasi geofisika metode geolistrik mampu untuk mengidentifikasi dan mengkarakterisasi patahan tersebut.

Undang-undang No. 26 Tahun 2008 tentang Rencana Tata Ruang Wilayah Nasional dijelaskan bahwa pemerintah kota atau daerah memegang peranan yang sangat penting dalam menyusun dan melaksanakan penataan ruang kawasan pesisir. Kota Manado sebagai ibu kota Provinsi Sulawesi Utara, memiliki peran strategis sebagai kota utama dengan fungsi sebagai pusat jasa, dan perdagangan di Sulawesi Utara dan sekitarnya. Kondisi ini ditunjang pula oleh posisi geografisnya di Pasific Rim yang strategis sebagai pintu masuk (entry point) ke kawasan ekonomi global, khususnya di Asia Pasifik (Poli dan Tinangon, 2018).

\section{Material dan Metode}

Eksplorasi metode geolistrik tahanan jenis merupakan metode eksplorasi geofisika yang ramah lingkungan dan tidak merusak. Pengambilan data dilakukan dengan mengalirkan arus listrik ke dalam tanah dari permukaan dengan mengggunakan dua buah elektroda. Selain itu terdapat dua elektroda lain yang berfungsi sebagai pengukur beda potensial listrik. Aturan posisi keempat elektroda yang digunakan adalah bentangan konfigurasi Dipol dipol. Data yang diperoleh dari pengukuran ini adalah kuat arus (I), beda potensial (V) dan jarak spasi a. Data topografi diperoleh dengan menggunakan GPS.

Penelitian dilakukan di Kelurahan Maasing Kecamatan Tuminting Kota Manado (Gambar 1). Studi pendahuluan dan orientasi lapangan menemukan bahwa daerah pesisir ini dilalui oleh jalan Boulevard, daerah yang dipenuhi dengan perumahan penduduk padat. Lintasan survei seperti pada Gambar 1, lintasan pengukuran 2 buah, spasi elektroda $10 \mathrm{~m}$, panjang bentangan $480 \mathrm{~m}$ dan 240 $m$ Akuisisi data geolistrik menggunakan alat multichannel and multielectrode resistivity and IP meter MAE X612EM. Eksplorasi geofisika Metode Geolistrik Konfigurasi Dipol-dipol Data hasil ukur resistivitymeter diolah dengan menggunaka software Res2Dinv.

Hasil perhitungan nilai tahanan jenis semu dibawah lintasan ukur hingga kedalaman tertentu sesuai dengan panjang bentangan yang digunakan, semakin panjang bentangan maka semakin dalam 
target yang dapat diketahui. Hasil olahan berupa tampang llintang resistivitas 2 dimensi yang menggambarkan kondisi lapisan tanah bawah permukaan. Nilai tahanan jenis yang relatif tinggi berasosiasi dengan batuan kering, batuan beku, bedrock ataupun lainnya. Sedangkan nilai tahanan jenis yang relatif rendah berasosiasi dengan batuan basah, lapisan penutup basah, saluran air/celah/retakan yang mengandung air ataupun logam. Sehingga dengan mengetahui jenis batuan atau geologi lokal setempat, nilai-nilai tahanan jenis tersebut dapat dikonversikan ke jenis batuan atau tanah atau struktur bawah permukaan.

Hasil olahan yang berupa cross section resistivitas lapisan bawah permukaan tanah dianalisis untuk mengetahui keberadaan patahan. Kedalaman patahan, lebar patahan dan posisi riil patahan akan diketahui lebih pasti. Metode ini merupakan salah satu sarana untuk menvalidasi keberadaan patahan pada peta geologi.

\section{Hasil dan Pembahasan}

Akuisisi data di lokasi penelitian dilaksanakan pada dua lintasan, Lintasan 1 dan Lintasan 2 dengan posisi lintasan tampak pada Gambar 1.

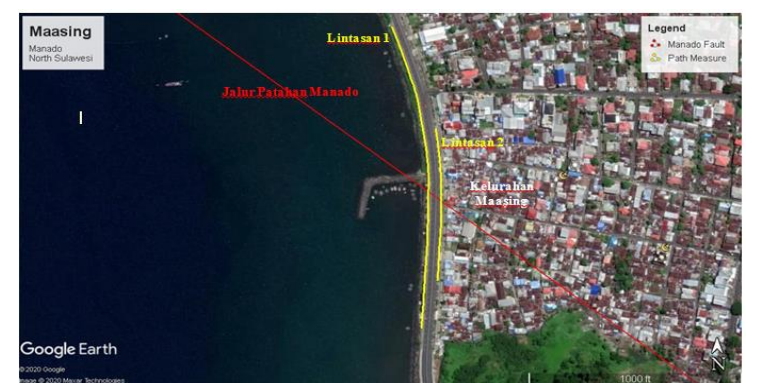

Gambar 1. Peta Lintasan akuisisi data pada lokasi penelitian

Eksplorasi geolistrik dari distrik Pur'ısimaRumicruz mengungkapkan hubungan yang nyata antara lapisan resistivitas rendah dan mineralisasi terletak di zona patahan. Sebagai akibat dari patahan, akan meningkatkan porositas dan permeabilitas akan menurunkan resistivitas sampai di bawah 150 ohm (Lopez, et al. 2012).

Gambar 2 menunjukkan hasil olahan pada lintasan 1, bidang lemah yang diindikasikan dengan resistivitas rendah dengan lemah $\rho \leq 20 \Omega$ m terletak pada posisi elektroda 22 - 23, bertepatan dengan meter ke 220 - 230. Garis lintasan 1 memotong garis Patahan Manado pada elektoroda 22 - 23 dan bertepatan dengan posisi rekahan. Dilihat dari sifat bidang lemah yang mempunyai bentuk tak beraturan, bidang lemah ini menerus sampai permukaan dan tersusun oleh material yang relatif lebih konduktif dari pada batuan disekitarnya dan diduga sebagai rekahan. Rekahan mempunyai lebar $10 \mathrm{~m}$ dibagian atas dan melebar sampai $60 \mathrm{~m}$ di bagian bawah, menempati ruang dari permukaan ( $0 \mathrm{~m}$ ) sampai kedalaman $20 \mathrm{~m}$.

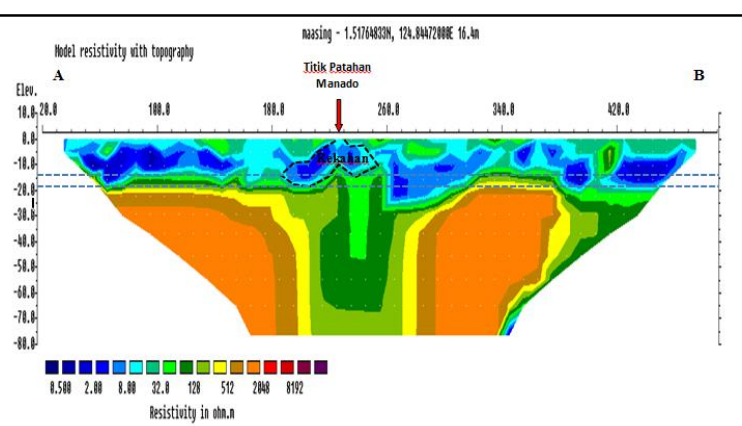

Gambar 2. Tampang lintang resistivitas pada Lintasan 1

Hasil ini mempunyai kemiripan dengan identifikasi yang dilakukan oleh Helen dkk, 2015 di Kecamatan Singkil yang melakukan pendugaan dengan geolistrik konfigurasi Wenner-Schlumberger, diidentifikasi sebagai rekahan, $\rho<20,9 \Omega$ m, lebar 65 $\mathrm{m}$, kedalaman sampai 28,7 m Lokasi rekahan tepat pada garis Patahan Manado.

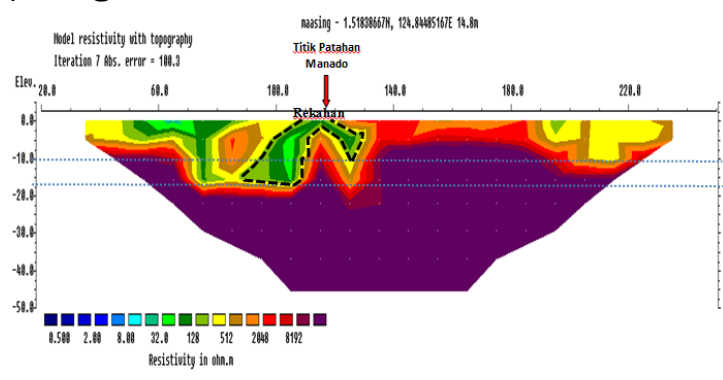

Gambar 3. Tampang lintang resistivitas pada Lintasan 2

Tampang lintang resistivitas bawah permukaan pada lintasan 2 ditunjukkan pada Gambar 3. Lintasan 2 memotong garis Patahan Manado pada antara elektroda 23 - 24, bersesuaian dengan meter ke 230 - 240. Pada lokasi lintasan 2 diperoleh zona lemah $\rho<128 \Omega \mathrm{m}$ pada elektroda 23 - 24, zona lemah pada lintasan 2 ini juga diidentifikasi sebagai rekahan karena mempunyai sifat yang sama dengan zona lemah pada lintasan 1. Rekahan mempunyai lebar $10 \mathrm{~m}$ di bagian atas dan $40 \mathrm{~m}$ di bagian bawah, menempati ruang dari permukaan sampai kedalaman $20 \mathrm{~m}$. Rekahan menempati posisi tepat pada garis Patahan Manado.

\section{Kesimpulan}

Patahan Manado di pesisir Pantai Manado diidentifikasi sebagai rekahan, posisi rekahan terletak di jalur Patahan Manado. Rekahan pada lintasan 1 mempunyai resistivitas $\rho \leq 20 \Omega \mathrm{m}$, lebar rekahan 10$60 \mathrm{~m}$ dan kedalaman sampai $20 \mathrm{~m}$. Pada lintasan 2 rekahan teridentifikasi dengan $\rho<20,9 \Omega \mathrm{m}$, lebar 65 $\mathrm{m}$, kedalaman sampai $28,7 \mathrm{~m}$.

\section{Daftar Pustaka}

Burbey, Thomas J; Seaton, William J. 2002. Evaluation of two-dimensional resistivity methods in a fractured crystalline-rock terrane. Journal of Applied Geophysics 51: 21-41.

Lopez, Luciano; Echeveste, Horatio; Tessone, Mario; Alperın, Marta; Etcheverry, Ricardo. 2012. Geoelectric Exploration of the Purısima-Rumicruz 
District, ' Jujuy Province, Argentina. International Journal of Geophysics. Volume 2012, Article ID 371059, 11 pages.

Poli, Hanny; Tinangon, Alvin J. 2011. Kajian Tataruang Wilayah Pesisir Kota Manado Menghadapi dampak Pemanasan Global. Media Matrasain 8.

Pondard, Nicolas and Barnest, P. M. 2010. Structure and paleoearthquake records of active submarine faults, Cook Strait, New Zealand: Implications for fault interactions, stress loading, and seismic hazard. Journal of Geophysical Research 115

Siahaan, Eben Ezer; Soemarinda, Sukusen; Fauzi, Amir; Silitonga, Timbul; Azimudin, Tafif; Raharjo, Imam B., 2005. Tectonism and Volcanism Study in the Minahasa Compartment of the North Arm of Sulawesi Related to Lahendong Geothermal Field, Indonesia. Proceedings World Geothermal Congress 2005. Antalya, Turkey.

Undang; 27; 2007. Pengelolaan Wilayah Pesisir dan pulau-pulau Kecil. 